慶應義塾大学学術情報リポジトリ

Keio Associated Repository of Academic resouces

\begin{tabular}{|c|l|}
\hline Title & Amino-sugar phosphates from the cell wall of micrococcus lysodeikticus \\
\hline Sub Title & \\
\hline Author & $\begin{array}{l}\text { 友田, 正司(Tomoda, Masashi) } \\
\text { Ud-Din, Nasir } \\
\text { Jeanloz, Roger W. }\end{array}$ \\
\hline Publisher & 共立薬科大学 \\
\hline Publication year & 1977 \\
\hline Jtitle & $\begin{array}{l}\text { 共立薬科大学研究年報 (The annual report of the Kyoritsu College of } \\
\text { Pharmacy). No.22 (1977. ) ,p.145-146 }\end{array}$ \\
\hline JaLC DOI & \\
\hline Abstract & \\
\hline Notes & 抄録 \\
\hline Genre & Technical Report \\
\hline URL & https://koara.lib.keio.ac.jp/xoonips/modules/xoonips/detail.php?koara_id=AN00062898-0000002 \\
2-0145
\end{tabular}

慶應義塾大学学術情報リポジトリ(KOARA)に掲載されているコンテンツの著作権は、それぞれの著作者、学会または出版社/発行者に帰属し、その権利は著作権法によって 保護されています。引用にあたっては、著作権法を遵守してご利用ください。

The copyrights of content available on the KeiO Associated Repository of Academic resources (KOARA) belong to the respective authors, academic societies, or publishers/issuers, and these rights are protected by the Japanese Copyright Act. When quoting the content, please follow the Japanese copyright act. 
No. 22 (1977)

\title{
Amino-Sugar Phosphates from the Cell Wall of Micrococcus Iysodeikticus *
}

\author{
Masashi TOMODA, NasiR-Ud-DiN**, and ROger W. Jeanloz** \\ 友田正司, Nasir-Ud-Din, Roger W. Jeanloz
}

The presence of muramic acid 6-phosphate in the cell walls of Micrococcus lysodeikticus and several other bacteria has been reported. We now report the isolation and characterization of glucosamine 6-phosphate, as well as of muramic acid 6-phosphate, from the lysozyme-resistant cell walls of Micrococcus lysodeikiticus.

The lysozyme-resistant material obtained from cell walls was treated with $4 \mathrm{~N}$ hydrochloric acid for $10 \mathrm{hr}$ at $80^{\circ}$. After evaporation, the acid-free residue in water was adsorbed on a column of Dowex $50 \mathrm{X}-8$ ion-exchange resin, and column was eluted with water. Three fractions were obtained. The first mainly contained D-glucose. The second fraction showed a single component on thin-layer chromatography (TLC) and reacted positively with ninhydrin, the Hanes-Isherwood and Park-Johnson reagents, and with the modified ElsonMorgan reagent to give an absorption maximum at $510 \mathrm{~nm}$., indicating the presence of a reducing sugar having amino and a phosphate group. Finally, treatment of the sugar phosphate with alkaline phosphatase liberated muramic acid.

In TLC, the third fraction showed a single component that gave a positive stain with ninhydrin and the Hanes-Isherwood reagent. The sugar was reducing, and gave a positive Elson-Morgan reaction with an absorption maximum at $530 \mathrm{~nm}$. Treatment of the sugar phosphate with alkaline phosphatase released a sugar, identical with glucosamine (TLC), which gave arabinose (TLC) on degradation with ninhydrin. Periodate treatment of $\mathrm{N}$-acetyl-glucosamine phosphate degraded the sugar, and no release of formaldehyde was detected. The results strongly suggest the presence of a phosphate group at C-6 of glucosamine.

In order to further establish that glucosamine 6-phosphate is an original sugar component of the cell walls and does not arise as the de-etherification product of muramic acid 6-phosphate during acid hydrolysis, synthetic muramic acid 6-phosphate was treated with various concentrations of hydrochloric acid for several time-intervals. The products of hydrolysis clearly indicate that the ether bond in muramic acid 6-phosphate is stable to the acid conditions used and that these treatments removed only the phosphate group. During acid hydrolysis, D-glucosamine 6-phosphate might arise from D-glucosamine 4-phosphate ; however, this seems unlikely, as the D-glucosamine residues in cell walls are linked at C-4, and non-reducing terminal 2-acetamido-2-deoxy-D-glucose residues were shown, by methylation studies, to be free of substituents.

*本報告は Carbohyd. Res., 57, C1 - C3 (1977) に発表

** Harvard University, U. S. A. 
No. 22 (1977)

As no inorganic phosphate was released by treatment of the non-dialyzable cell wall with alkaline phosphatase, it is probable that the D-glucosamine 6-phosphate residues serve, like the muramic acid 6-phosphate residues, as a link between the antigenic polysaccharide chains and the peptidoglycan chain. 